\title{
Pengaruh Pola Asuh Orang Tua Terhdap Hasil Belajar Matematika dengan Efikasi Diri Sebagai Intervening
}

\author{
Ni Putu Diah Fitasari ${ }^{1 *}$, Ni Wayan Suniasih ${ }^{2}$, Gusti Ngurah Sastra Agustika ${ }^{3}$
}

${ }^{123}$ Universitas Pendidikan Ganesha, Indonesia

\section{A R T I C LE I N F O Article history: \\ Received 18 August 2019 Received in revised form 19 September 2019 Accepted 25 October 2019 Available online 30 November 2019}

\section{Kata Kunci:}

Asuh Orang Tua, Efikasi Diri, Hasil Belajar

Matematika, Intervening

Keywords:

Parenting Styles, Selfefficacy, Mathematics Learning Outcomes, Intervening

\begin{abstract}
A B S T R A K
Penelitian ini bertujuan untuk mengetahui pengaruh pola asuh orang tua terhadap hasil belajar matematika, pengaruh efikasi diri terhadap hasil belajar matematika dan pengaruh pola asuh orang tua terhadap hasil belajar matematika dengan dimediasi efikasi diri. Dalam penelitian ini, sampel yang digunakan adalah 149 siswa kelas V SD Gugus IV Kecamatan Gianyar. Metode pengumpulan data menggunakan teknik non tes. Jenis penelitian ini merupakan penelitian ex post facto dengan menggunakan analisis jalur sebagai metode analisis. Hasil pengujian hipotesis menunjukan bahwa: 1) terdapat pengaruh yang signifikan pola asuh orang tua kategori otoriter terhadap hasil belajar matematika sebesar $25.2 \%$; 2) terdapat pengaruh yang signifikan pola asuh orang tua kategori demokratis terhadap hasil belajar matematika sebesar $26.8 \%$; 3) terdapat pengaruh yang signifikan pola asuh orang tua kategori permisif terhadap hasil belajar matematika sebesar $11.6 \%$; 4) terdapat pengaruh yang signifikan efikasi diri terhadap hasil belajar matematika sebesar $66.6 \%$; 5) terdapat pengaruh yang signifikan pola asuh orang tua kategori otoriter terhadap hasil belajar matematika melalui efikasi diri sebesar $26.3 \%$; 6 ) terdapat pengaruh yang signifikan pola asuh orang tua kategori demokratis terhadap hasil belajar matematika melalui efikasi diri sebesar $39.3 \%$; 7) terdapat pengaruh yang signifikan pola asuh orang tua kategori permisif terhadap hasil belajar matematika melalui efikasi diri sebesar $25.2 \%$.
\end{abstract}

\section{A B S T R A C T}

This research aims to determine the effect of parenting styles on mathematics learning outcomes, the effect of self-efficacy on mathematics learning outcomes and the effect of parenting styles on mathematics learning outcomes mediated with self-efficacy. In this research, the sample used was 149 fifth grade students of Elementary School Cluster IV Gianyar Sub district. Data collection methods use is non-test techniques. The analytical method used is path analysis. The results of hypothesis testing show: 1) there is a significant effect of parenting styles authoritarian category on mathematics learning outcomes by $25.2 \%$; 2) there is a significant effect of parenting styles authoritative category on the mathematics learning outcomes by $26.8 \%$; 3 ) there is a significant effect of parenting styles in the permissive category on mathematics learning outcomes by $11.6 \% ; 4$ ) there is a significant effect of self-efficacy on mathematics learning by $66.6 \%$; 5) there is a significant effect on the parenting styles authoritarian category on mathematics learning outcomes through selfefficacy by $26.3 \%$; 6) there is a significant effect of parenting styles authoritative category on mathematics learning outcomes through self-efficacy by $39.3 \%$; 7 ) there is a significant effect of parenting styles permissive category on mathematics learning outcomes through self-efficacy by $25.2 \%$.

\footnotetext{
${ }^{1}$ Corresponding author.

E-mail addresses: ni.pt.diah.fitasari@undiksha.ac.id (Ni Putu Diah Fitasari)
} 


\section{Pendahuluan}

Mata pelajaran matematika masih dianggap sulit, membosankan, serta menakutkan bagi sebagian siswa. Hal tersebut menyebabkan siswa kurang yakin belajar matematika. Keyakinan dalam situasi ini disebut efikasi diri. Menurut Bandura (dalam Santrock, 2007:286) efikasi diri merupakan keyakinan seseorang dalam menguasai situasi dan menghasilkan hal positif. Misalnya anak dengan efikasi diri rendah mungkin tidak mau berusaha belajar untuk mengerjakan ujian karena ia tidak percaya bahwa belajar dapat membantunya mengerjakan soal. Sedangkan anak dengan efikasi diri lebih tinggi akan berusaha dan yakin terhadap usaha belajarnya. Berdasarkan penelitian Fitriana, dkk (2015) efikasi diri berpengaruh signifikan secara langsung terhadap hasil belajar matematika dengan tingkat kepercayaan 93\%. Hal tersebut menunjukan semakin besar efikasi diri dalam belajar matematika, maka semakin besar hasil belajar yang diperoleh siswa.

Rendahnya efikasi diri dinilai menjadi salah satu faktor internal rendahnya hasil belajar matematika pada anak sehingga, anak memerlukan dukungan dalam proses belajarnya. Orang tua dinilai memegang peranan penting dalam proses belajar anak. Orang tua memiliki tanggung jawab terhadap anaknya sehingga, orang tua sangat berperan dalam meningkatkan pendidikan anaknya. Menurut Baumrind (dalam Santrock, 2007) terdapat 4 gaya pengasuhan authoritarian (otoriter), authoritative (demokratis), neglectfull dan indulgent (permisif). Keterlibatan orang tua dalam belajar mampu memprediksi prestasi anak. Partisipasi orang tua dalam membantu tugas anak dinilai mampu meningkatkan rasa percaya diri anak terhadap kemampuan mereka dan akan mengarah pada hasil belajar anak, (Brooks, 2011)

Namun, kenyataannya, masih banyak orang tua yang memilih pengasuh untuk mengasuh anak mereka. Banyak orang tua yang memilih pengasuh karena orang tua saat ini lebih sibuk dengan pekerjaannya. Kurangnya pendampingan belajar pada anak dapat menurunkan keyakinan anak dalam belajar karena anak merasa kurang diperhatikan. Hal tersebut akan berdampak pada hasil belajar anak terlebih dalam mata pelajaran matematika.

Secara teoretis keyakinan diri pada anak tumbuh dengan adanya dukungan dari orang tua. Pola asuh yang tepat serta efikasi diri yang tinggi akan memengaruhi hasil belajar pada anak. Hal ini perlu dibuktikan secara empiris bahwa pola asuh dan efikasi diri dapat memengaruhi hasil belajar matematika siswa. Berdasarkan latar belakang tersebut peneliti tergerak untuk melakukan penelitian dengan judul "Pengaruh Pola Asuh Orang Tua terhadap Hasil Belajar Matematika dengan Efikasi Diri sebagai Variabel Intervening pada Siswa Kelas V SD Gugus IV Kecamatan Gianyar 2017/2018" sehingga jika terbukti s ecara empiris bahwa pola asuh orang tua serta efikasi diri memengaruhi hasil belajar matematika maka, orang tua perlu memperhatikan pola asuh yang diterapkan dalam mendidik serta mampu menumbuhkan efikasi diri yang tinggi pada anak.

Proses belajar dikatakan efisien apabila usaha dalam belajar mencapai hasil yang tinggi. Hasil belajar adalah kemampuan yang diperoleh anak melalui kegiatan belajar. Beberapa mata pelajaran masih dijadikan tolak ukur dalam hasil belajar siswa. Matematika merupakan salah satu mata pelajaran yang dinilai sangat berpengaruh dalam kehidupan siswa. Namun, mata pelajaran matematika masih dianggap sulit, membosankan, serta menakutkan bagi sebagian siswa. Hal tersebut menyebabkan siswa kurang yakin belajar matematika. Keyakinan dalam hal ini disebut efikasi diri.

Menurut Suprijono (2012:5), hasil belajar adalah polapola perbuatan, nilai-nilai, pengertianpengertian, sikapsikap, apresiasi dan keterampilan. Selanjutnya Supratiknya (2012 : 5) mengemukakan bahwa hasil belajar yang menjadi objek penilaian kelas berupa kemampuan-kemampuan baru yang diperoleh siswa setelah mereka mengikuti proses belajar-mengajar tentang mata pelajaran tertentu. Dalam sistem pendidikan nasional rumusan tujuan pendidikan mengacu pada klasifikasi hasil belajar dari Bloom yang secara garis besar yaitu aspek kognitif, aspek afektif dan aspek psikomotor (Widodo, 2013).

Efikasi diri adalah keyakinan bahwa seseorang dapat menguasai situasi dan menghasilkan hasil positif. Anak yang memiliki efikasi diri rendah cenderung tidak mau berusaha belajar karena percaya bahwa belajar tidak dapat membantunya mengerjakan soal sedangkan anak yang memiliki efikasi diri tinggi cenderung menyukai tantangan. Maka, dengan efikasi diri yang tinggi anak akan mampu mencapai hasil belajar yang baik terutama dalam mata pelajaran matematika.

Mengembangkan efikasi diri membutuhkan dorongan dari lingkungan terdekat siswa. Orang tua dinilai memilki peranan penting dalam proses belajar siswa. Dorongan dari orang tua akan mampu meningkatkan keyakinan anak untuk melewati proses belajarnya. Namun, setiap orang tua memiliki pola pengasuhan yang berbeda-beda. Dengan pola pengasuhan yang berbeda, karakter serta perilaku anak yang terbentuk akan berbeda pula. Pola asuh orang tua adalah upaya orang tua dalam menjaga dan membimbing anak dari sejak dilahirkan hingga remaja. Beberapa orang tua mendukung anaknya sedangkan ada beberapa orang tua lainnya mengacuhkan bahkan tidak peduli dengan anaknya, hal ini 
tentunya akan menimbulkan perkembangan yang berbeda pada setiap anak sehingga, pengasuhan yang dilakukan orang tua dinilai memiliki peranan dalam membentuk efikasi diri anak.

Tujuan penelitian ini: 1) untuk mengetahui pengaruh yang signifikan pola asuh orang tua kategori otoriter terhadap hasil belajar matematika pada siswa kelas V SD Gugus IV Kecamatan Gianyar 2017/2018; 2) untuk mengetahui pengaruh yang signifikan pola asuh orang tua kategori demokratis terhadap hasil belajar matematika pada siswa kelas V SD Gugus IV Kecamatan Gianyar 2017/2018; 3) untuk mengetahui pengaruh yang signifikan pola asuh orang tua kategori permisif terhadap hasil belajar matematika pada siswa kelas V SD Gugus IV Kecamatan Gianyar 2017/2018; 4) untuk mengetahui pengaruh yang signifikan efikasi diri terhadap hasil belajar matematika pada siswa kelas V SD Gugus IV Kecamatan Gianyar 2017/2018; 5)untuk mengetahui pengaruh yang signifikan pola asuh orang tua kategori otoriter terhadap hasil belajar matematika dengan efikasi diri sebagai variabel intervening pada siswa kelas V SD Gugus IV Kecamatan Gianyar 2017/2018; 6) untuk mengetahui pengaruh yang signifikan pola asuh orang tua kategori demokratis terhadap hasil belajar matematika dengan efikasi diri sebagai variabel intervening pada siswa kelas V SD Gugus IV Kecamatan Gianyar 2017/2018; 7) untuk mengetahui pengaruh yang signifikan pola asuh orang tua kategori permisif terhadap hasil belajar matematika dengan efikasi diri sebagai variabel intervening pada siswa kelas V SD Gugus IV Kecamatan Gianyar 2017/2018.

\section{Metode}

Penelitian ini dilaksanakan pada semester genap di kelas V SD Gugus IV Kecamatan Gianyar. Jenis penelitian ini merupakan penelitian ex post facto. Analisis penelitian ini menggunakan analisis jalur (path analysis). Populasi dalam penelitian ini adalah seluruh siswa kelas V SD Gugus IV Kecamatan Gianyar Tahun Pelajaran 2017/2018. Gugus IV Kecamatan Gianyar terdiri dari 6 sekolah negeri dengan total jumlah siswa 149 siswa. Teknik sampling yang digunakan adalah teknik sampling jenuh dimana seluruh populasi dijadikan sampel. Metode pengumpulan data penelitian ini menggunakan metode non tes yaitu kuesioner (angket) dan meneliti dokumen-dokumen. Kuesioner yang digunakan dalam penelitian ini digunakan untuk indikator pola asuh orang tua serta efikasi diri. Kuesioner bersifat tertutup, sehingga proses pengolahan datanya lebih mudah sebab jawaban-jawaban pada kuesioner tertutup memiliki jawaban standar. Kuesioner yang disusun, menggunakan model skala likert sehingga akan memudahkan respondan dalam menjawab pertanyaan atau pernyataan yang telah disediakan dalam kuesioner tersebut. Kuesioner terdiri dari dua item yaitu item positif dan negatif. Model skala likert yang digunakan dalam penelitian ini adalah skala likert dengan empat tingkatan jawaban. Uji instrumen pada kuesioner menggunakan uji validitas dan reliabilitas kemudian dilanjutkan dengan menganalisis data. Sebelum melakukan analisis data terlebih dahulu dilakukan uji prasyarat yaitu uji normalitas dengan rumus kolmogorov-smirnov dan uji linieritas dengan scatter plot .

Terdapat 2 substruktur yang akan diuji. Substruktur 1 adalah menganalisis data pola asuh orang tua terhadap efikasi diri. Berikut gambar sub struktur 1.

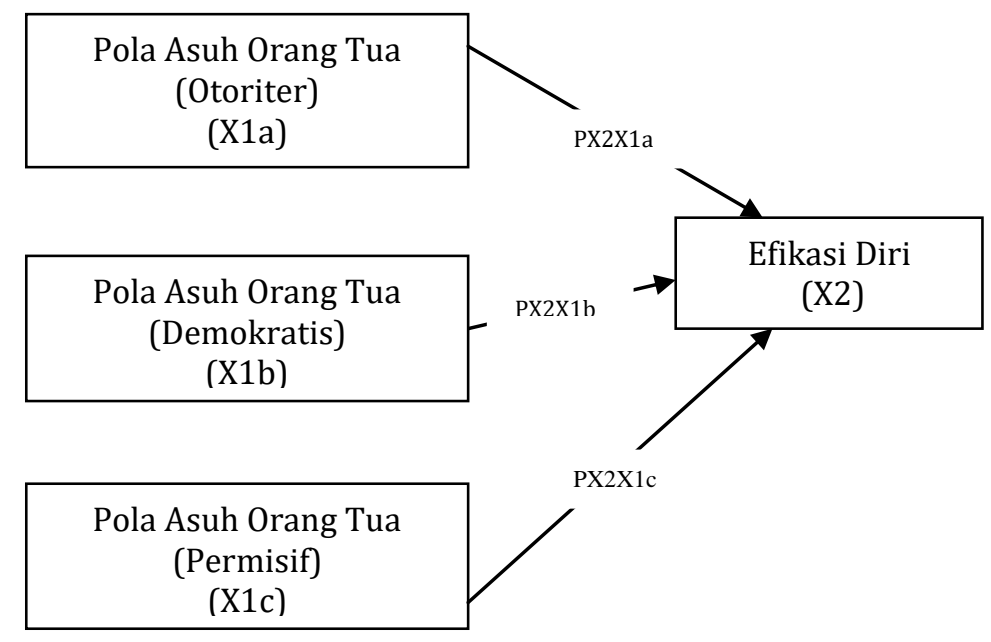

Gambar 1.Model Analisis Jalur Substruktur 1 
Sedangkan untuk substruktur 2 adalah substruktur yang menganalisis data pola asuh orang tua dan efikasi diri terhadap hasil belajar matematika. Berikut gambar substruktur 2.

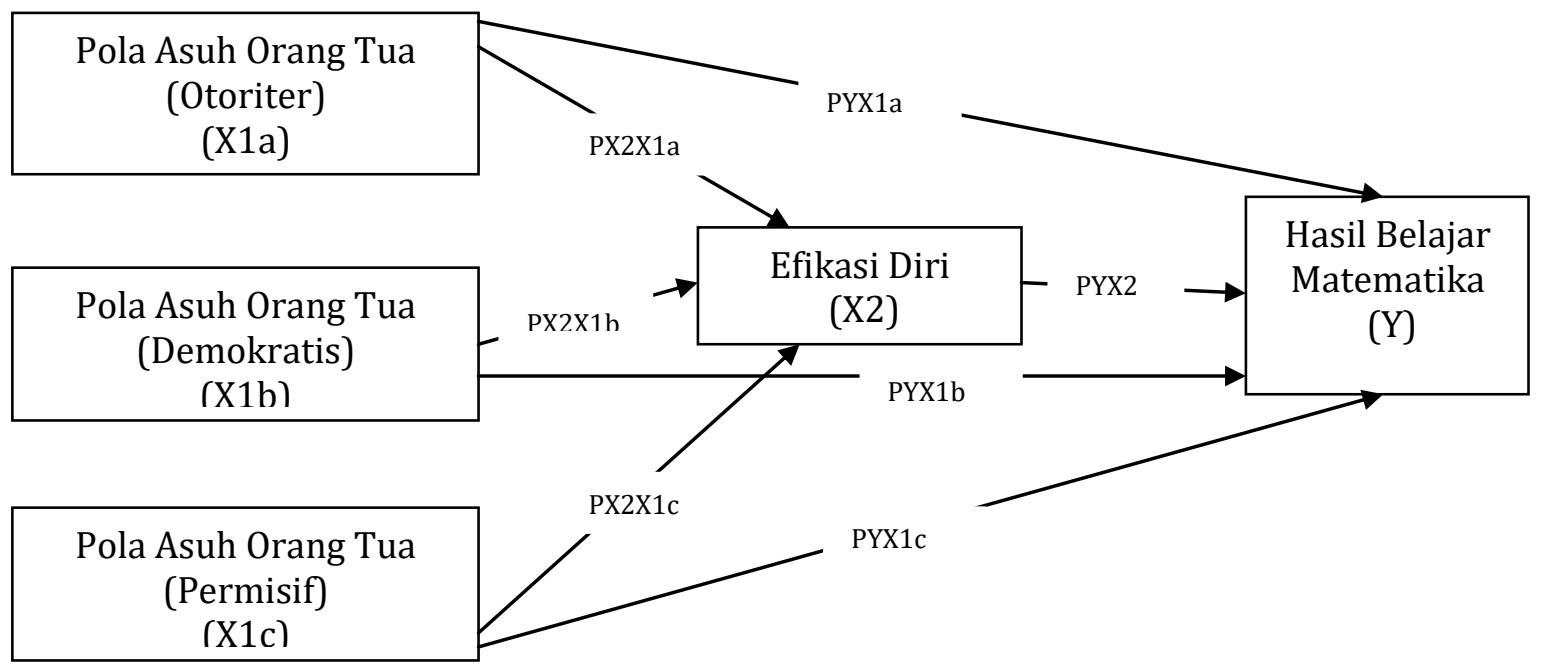

Gambar 2. Model Analisis Jalur Substruktur 2

\section{Hasil dan Pembahasan}

Sebelum melakukan uji hipotesis, dilakukan uji prasyarat terlebih dahulu yaitu uji normalitas sebaran data dan uji linieritas. Berdasarkan hasil analisis uji normalitas data di bawah ini disajikan rekapitulasi hasil uji normalistas sebaran data pola asuh orang tua, efikasi diri, dan hasil belajar matematika siswa kelas V SD Gugus IV Kecamatan Gianyar.

Tabel 1. Rekapitulasi Hasil Uji Normalitas Pola Asuh Orang Tua, Efikasi Diri, dan Hasil Belajar Matematika

\begin{tabular}{cccc}
\hline Variabel & Ks hitung & Ks tabel & Keterangan \\
\hline Pola Asuh Orang Tua (otoriter) & 0.065 & 0.111 & Berdistribusi Normal \\
Pola Asuh Orang Tua (demokratis) & 0.108 & 0.111 & Berdistribusi Normal \\
Pola Asuh Orang Tua (permisif) & 0.075 & 0.111 & Berdistribusi Normal \\
Efikasi Diri & 0.080 & 0.111 & Berdistribusi Normal \\
Hasil Belajar Matematika & 0.094 & 0.111 & Berdistribusi Normal \\
\hline
\end{tabular}

Uji Linieritas dilakukan untuk mengetahui apakah dua variabel mempunyai hubungan yang linier atau tidak secara signifikan. Uji linieritas menggunakan metode Scatter Plot. Uji linieritas dengan metode scatter plot dilakukan dengan melihat kurva. Data dinyatakan linier apabila titik-titik pada gambar distribusi data yang menyebar di sekitar garis diagonal searah dengan garis diagonal. Data pada penelitian ini dinyatakan linier karena penyebarannya mengikuti garis diagonal.

Hipotesis yang diuji dalam penelitian ini adalah HO yaitu, (1) tidak terdapat pengaruh yang signifikan pola asuh orang tua terhadap hasil belajar matematika pada siswa kelas V SD Gugus IV Kecamatan Gianyar 2017/2018, (2) tidak terdapat pengaruh yang signifikan pola asuh orang tua terhadap hasil belajar matematika dengan efikasi diri sebagai variabel intervening pada siswa kelas V SD Gugus IV Kecamatan Gianyar 2017/2018.

Analisis regresi yang pertama, menganalisis variabel pola asuh orang tua dengan efikasi diri untuk mengetahui pengaruh antara pola asuh orang tua terhadap efikasi diri. Analisis regresi yang kedua, menganalisis pengaruh pola asuh orang tua dan efikasi diri terhadap hasil belajar matematika. Analisis menggunakan bantuan aplikasi IBM SPSS Statistics 23. Berdasarkan uji analisis untuk substruktur 1 diperoleh hasil sebagai berikut. 
Tabel 2. Hasil Uji Substruktur 1: Pola Asuh Orang Tua dengan Efikasi Diri

\begin{tabular}{|c|c|c|c|c|c|c|c|}
\hline \multicolumn{2}{|c|}{ Hubungan } & \multirow{2}{*}{$\begin{array}{c}\text { Koefisien } \\
\text { Jalur }\end{array}$} & \multirow{2}{*}{ thitung } & \multirow{2}{*}{ Sig } & \multirow{2}{*}{ Fhitung } & \multirow{2}{*}{ Sig } & \multirow{2}{*}{$\mathrm{R} 2$} \\
\hline Dari & $\mathrm{Ke}$ & & & & & & \\
\hline $\mathrm{X} 1 \mathrm{a}$ & & -0.395 & -5.682 & 0.000 & & & \\
\hline $\begin{array}{l}X 1 b \\
X 1 c\end{array}$ & $\mathrm{X} 2$ & $\begin{array}{r}0.590 \\
-0.379\end{array}$ & $\begin{array}{r}7.586 \\
-5.010\end{array}$ & $\begin{array}{l}0.000 \\
0.000\end{array}$ & 25.263 & 0.000 & 0.343 \\
\hline
\end{tabular}

Berdasarkan tabel diatas, nilai Fhitung $=25.263>$ Ftabel $=2.70$, hal ini berarti variabel X1a, X1b dan X1c secara simultan berpengaruh terhadap variabel X2. Selanjutnya, pengujian secara individual dilakukan dengan membandingkan signifikansi thitung. Berdasarkan analisis perhitungan, variabel X1a, $\mathrm{X} 1 \mathrm{~b}$ dan X1c diperoleh signifikansi $0.000<0.05$ sehingga dapat disimpulkan terdapat pengaruh signifikan antara X1a, X1b dan X1c dengan X2. R2 yang diperoleh sebesar 0.343 menunjukan 34.3\% proporsi variasi efikasi diri dapat dipengaruhi pola asuh orang tua, sedangkan $65.7 \%$ sisanya dipengaruhi oleh faktor lain yang tidak dianalisis dalam penelitian ini. Berdasarkan hasil tersebut diperoleh model substruktur 1 berdasarkan koefisien jalurnya.

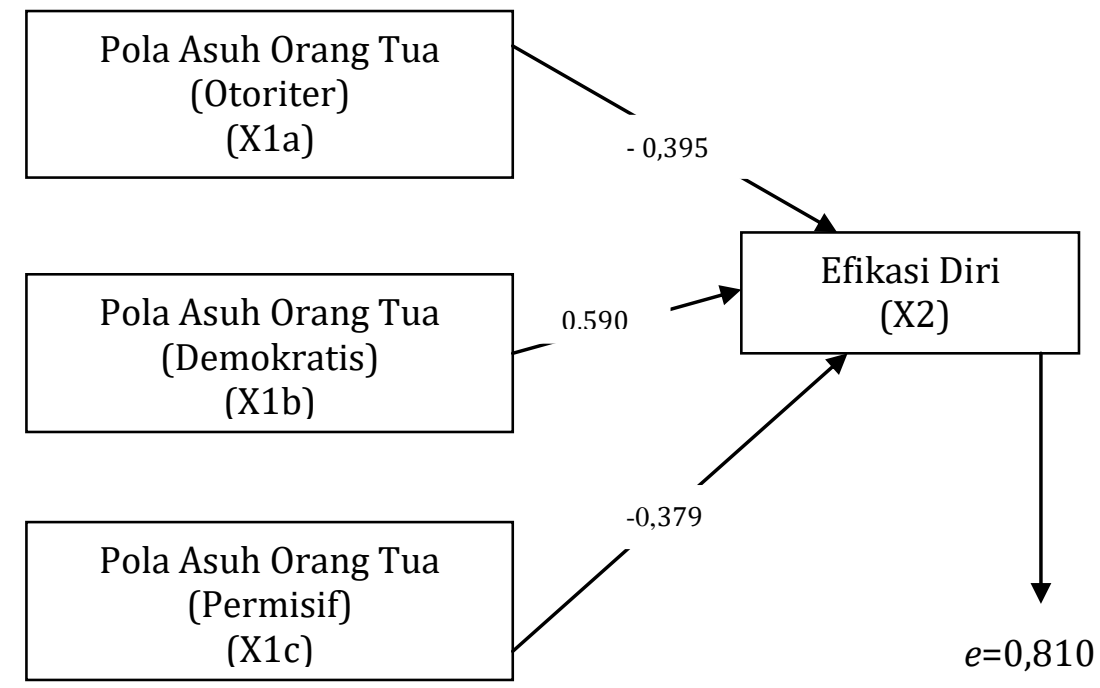

Gambar 3. Model Analisis Jalur Substruktur 1 dan Koefisien Jalurnya

Sedangkan untuk substruktur 2 diperoleh hasil sebagai berikut.

Tabel 3. Hasil Uji Substruktur 2: Pola Asuh Orang Tua dan Efikasi Diri

\begin{tabular}{|c|c|c|c|c|c|c|c|}
\hline \multicolumn{2}{|c|}{ Hubungan } & Koefisien & Thitung & Sig & Fhitung & Sig & $\mathrm{R} 2$ \\
\hline Dari & $\mathrm{Ke}$ & Jalur & Intung & SIg & Fmitung & SIg & K2 \\
\hline $\begin{array}{l}\text { X1a } \\
\text { X1b } \\
\text { X1c } \\
\text { X2 }\end{array}$ & Y & $\begin{array}{c}-0.252 \\
0.268 \\
0.116 \\
0.666\end{array}$ & $\begin{array}{c}-5.598 \\
4.980 \\
2.413 \\
13.683\end{array}$ & $\begin{array}{l}0.000 \\
0.000 \\
0.017 \\
0.000\end{array}$ & 124.784 & 0.000 & 0.776 \\
\hline
\end{tabular}

Berdasarkan tabel diatas, nilai Fhitung $=124.784>$ Ftabel $=2.46$, hal ini berarti variabel X1a, X1b, X1c dan X2 secara simultan berpengaruh terhadap variabel Y. Selanjutnya, pengujian secara individual dilakukan dengan membandingkan signifikansi thitung. Berdasarkan analisis perhitungan, variabel X1a, X1b, X1c dan X2 diperoleh signifikansi $0.000<0.05$ dan $0.017<0.05$ sehingga dapat disimpulkan terdapat pengaruh signifikan antara X1a, X1b, X1c dan X2 dengan Y. R2 yang diperoleh sebesar 0.776 menunjukan $77.6 \%$ proporsi variasi hasil belajar matematika dapat dipengaruhi pola asuh orang tua dan efikasi diri, sedangkan $22.4 \%$ sisanya dipengaruhi oleh faktor lain yang tidak dianalisis dalam penelitian ini. Berdasarkan hasil tersebut diperoleh model substruktur 2 berdasarkan koefisien jalurnya. 


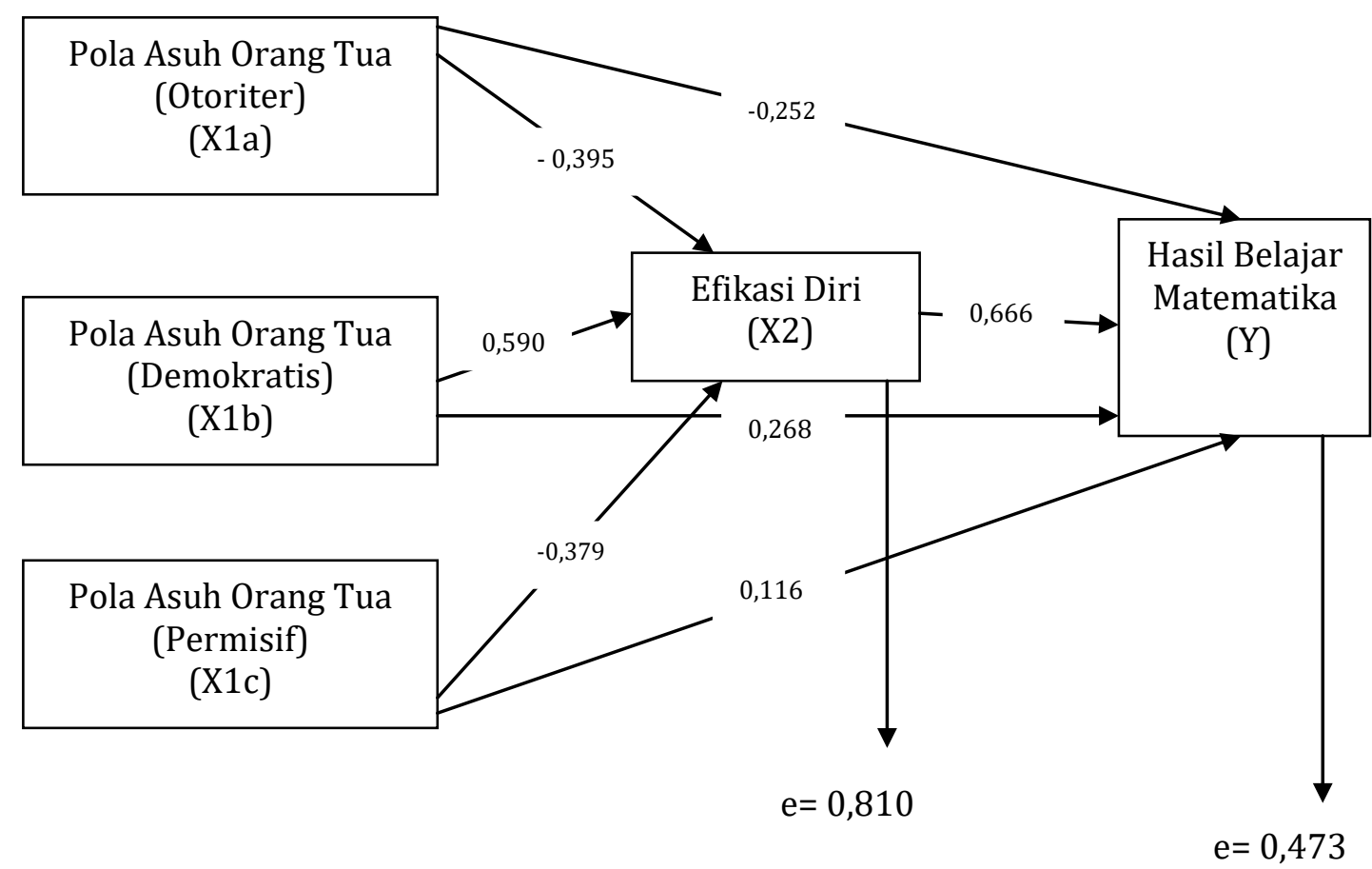

Gambar 4. Model Analisis Jalur Substruktur 2 dan Koefisien Jalurnya

Berdasarkan hasil pemaparan diatas diperoleh ringkasan data hasil analisis pengaruh langsung dan pengaruh tidak langsung sebagai berikut.

Tabel 4 Ringkasan Data Hasil Analisis Pengaruh Langsung dan Tidak Langsung

\begin{tabular}{ccccc}
\hline No. & Variabel & $\begin{array}{c}\text { Pengaruh Langsung } \\
\text { (DE) }\end{array}$ & $\begin{array}{c}\text { Pengaruh Tidak } \\
\text { Langsung (IE) }\end{array}$ & Pengaruh Total \\
\hline 1 & $\begin{array}{c}\text { Pola Asuh Orang Tua } \\
\text { Kategori Otoriter } \\
\text { Pola Asuh Orang Tua } \\
\text { Kategori Demokratis } \\
2\end{array}$ & -0.252 & -0.263 & -0.515 \\
3 & $\begin{array}{c}\text { Pola Asuh Orang Tua } \\
\text { Kategori Permisif }\end{array}$ & 0.268 & 0.393 & 0.661 \\
\hline
\end{tabular}

Berdasarkan hasil analisis data yang telah dilakukan terhadap masing-masing variabel penelitian diperoleh pembahasan sebagai berikut.

1. Pengaruh Pola Asuh Orang Tua Kategori Otoriter terhadap Hasil Belajar Matematika

Berdasarkan hasil pengujian hipotesis, pola asuh orang tua kategori otoriter terhadap hasil belajar matematika memperoleh nilai koefisien jalur sebesar $25.2 \%$ dengan signifikansi $0.000<0.05$ sehingga, H1 yang menyatakan terdapat pengaruh yang signifikan pola asuh orang tua kategori otoriter terhadap hasil belajar matematika pada siswa kelas V SD Gugus IV Kecamatan Gianyar 2017/2018 diterima. Nilai koefisien regresi yang diperoleh bertanda negatif, hal ini menunjukan bahwa nilai pola asuh orang tua kategori otoriter berbanding terbalik dengan hasil belajar matematika siswa. Semakin besar pola asuh otoriter yang diterapkan orang tua maka hasil belajar matematika yang diperoleh siswa akan semakin kecil. Hal ini konsisten dengan penelitian yang dilakukan oleh Budang dkk (2017) yang menemukan bahwa pola asuh otoriter memiliki korelasi yang bersifat negatif yakni sebesar $50.3 \%$. Baumrind (dalam Santrock 2007) menyatakan anak-anak dari orang tua yang otoriter sering kali berperilaku tidak kompeten.

2. Pengaruh Pola Asuh Orang Tua Kategori Demokratis terhadap Hasil Belajar Matematika

Berdasarkan hasil pengujian hipotesis, pola asuh orang tua kategori demokratis terhadap hasil belajar matematika memperoleh nilai koefisien jalur sebesar 26.8\% dengan signifikansi $0.000<0.05$ sehingga H2 yang menyatakan terdapat pengaruh yang signifikan pola asuh orang tua kategori 
demokratis terhadap hasil belajar matematika pada siswa kelas V SD Gugus IV Kecamatan Gianyar 2017/2018 dapat diterima. Nilai koefisien jalur yang diperoleh bertanda positif, hal ini menunjukan bahwa semakin besar pola asuh demokratis yang diterapkan orang tua maka hasil belajar matematika yang diperoleh siswa akan semakin besar. Hal ini konsisten dengan penelitian yang dilakukan oleh Budang, dkk (2017) yang menemukan bahwa pola asuh demokratis memiliki korelasi yang bersifat positif dengan nilai $89.6 \%$. Hal ini juga didukung dengan pernyataan Lestari (2012) yang menganggap bahwa pola asuh demokratis adalah pola asuh yang paling baik.

\section{Pengaruh Pola Asuh Orang Tua Kategori Permisif terhadap Hasil Belajar Matematika}

Berdasarkan hasil pengujian hipotesis, pola asuh orang tua kategori permisif terhadap hasil belajar matematika memperoleh nilai koefisien jalur sebesar $11.6 \%$ dengan signifikansi $0.017<0.05$ sehingga H3 yang menyatakan terdapat pengaruh yang signifikan pola asuh orang tua kategori permisif terhadap hasil belajar matematika pada siswa kelas V SD Gugus IV Kecamatan Gianyar 2017/2018 dapat diterima. Nilai koefisien jalur yang diperoleh bertanda positif, hal ini menunjukan bahwa pola asuh permisif memberi kontribusi untuk hasil belajar matematika siswa. Hal ini berbeda dengan penelitian yang dilakukan Budang dkk (2017) yang menyatakan tidak ada hubungan pola asuh permisif terhadap hasil belajar matematika. Namun, Garcia \& Gracia (2009) menyatakan pola asuh permisif dapat menghasilkan outcomes yang lebih baik. Pernyataan tersebut konsisten dengan Lestari (2012) yang menyatakan orang tua dengan gaya pengasuhan permisif cenderung menjadi sumber daya pemenuhan segala kebutuhan anaknya. Sehingga dapat disimpulkan bahwa pemenuhan kebutuhan tersebut dapat memaksimalkan potensi anak dalam mencapai hasil belajar yang baik. Dengan demikian pola asuh permisif yang diterapkan orang tua siswa Gugus IV Kecamatan Gianyar adalah pola asuh permisif-indulgent atau permisif- memanjakan.

\section{Pengaruh Efikasi Diri terhadap Hasil Belajar Matematika}

Berdasarkan hasil pengujian hipotesis, efikasi diri terhadap hasil belajar matematika memperoleh nilai koefisien jalur sebesar $66.6 \%$ dengan signifikansi $0.000<0.05$ sehingga H4 yang menyatakan terdapat pengaruh yang signifikan efikasi diri terhadap hasil belajar matematika pada siswa kelas V SD Gugus IV Kecamatan Gianyar 2017/2018 dapat diterima. Nilai koefisien jalur yang diperoleh bertanda positif, hal ini menunjukan bahwa efikasi memberi kontribusi untuk hasil belajar matematika siswa dimana semakin besar efikasi diri maka hasil belajar matematika yang diperoleh siswa juga baik. Hal ini konsisten dengan hasil penelitian Fitriana, dkk (2015) yang menyatakan bahwa efikasi diri berpengaruh signifikan secara langsung terhadap hasil belajar dengan tingkat kepercayaan $93 \%$.

\section{Pengaruh Pola Asuh Orang Tua Kategori Otoriter terhadap Hasil Belajar Matematika dengan Efikasi Diri sebagai Intervening}

Berdasarkan hasil analisis jalur, pengaruh pola asuh orang tua kategori otoriter terhadap hasil belajar matematika melalui efikasi diri yang diperoleh yaitu $26.3 \%$. Pengaruh langsung pola asuh orang tua kategori otoriter terhadap hasil belajar matematika yang diperoleh $25.2 \%$ dengan demikian pengaruh total yang diperoleh sebesar 51.5\%. Berdasarkan hasil tersebut pengaruh tidak langsung dari pola asuh orang tua otoriter memperoleh nilai lebih besar dari pengaruh langsungnya. Nilai yang diperoleh menunjukan adanya pengaruh negatif antara pola asuh kategori otoriter terhadap hasil belajar matematika melalui efikasi diri. Sehingga, semakin besar pola asuh otoriter yang diterapkan maka akan berdampak pada efikasi diri anak, sehingga hal tersebut memengaruhi menurunnya hasil belajar matematika anak. Hal ini sejalan dengan teori yang dipaparkan Slameto (2010) dimana hasil belajar dipengaruhi oleh faktor intern salah satunya yaitu faktor psikologis dan faktor ekstern salah satunya yaitu keluarga.

\section{Pengaruh Pola Asuh Orang Tua Kategori Demokratis terhadap Hasil Belajar Matematika dengan Efikasi Diri sebagai Intervening}

Berdasarkan hasil analisis jalur, pengaruh pola asuh orang tua kategori demokratis terhadap hasil belajar matematika melalui efikasi diri yang diperoleh yaitu 39.3\%. Pengaruh langsung pola asuh orang tua kategori demokratis terhadap hasil belajar matematika yang diperoleh $26.8 \%$ dengan demikian pengaruh total yang diperoleh sebesar $66.1 \%$. Berdasarkan hasil tersebut pengaruh tidak langsung dari pola asuh orang tua demokratis memperoleh nilai lebih besar dari pengaruh langsungnya. Nilai yang diperoleh menunjukan adanya pengaruh positif antara pola asuh kategori demokratis terhadap hasil belajar matematika melalui efikasi diri. Hasil ini menunjukan bahwa semakin besar pola asuh demokratis yang diterapkan maka akan berdampak pada efikasi diri anak, sehingga hal tersebut memengaruhi hasil belajar matematikanya. Hal ini didukung oleh pendapat Baumrind (dalam Santrock, 2007) yang 
menyatakan pola asuh demokratis memberi dampak positif terhadap anak serta pendapat Lestari (2012) yang menganggap bahwa pola asuh demokratis adalah pola asuh yang paling baik.

7. Pengaruh Pola Asuh Orang Tua Kategori Permisif terhadap Hasil Belajar Matematika dengan Efikasi Diri sebagai Intervening

Berdasarkan hasil analisis jalur, pengaruh pola asuh orang tua kategori permisif terhadap hasil belajar matematika melalui efikasi diri yang diperoleh yaitu 25.2\%. Pengaruh langsung pola asuh orang tua kategori permisif terhadap hasil belajar matematika yang diperoleh $11.6 \%$ sehingga pengaruh total yang diperoleh sebesar $13.6 \%$. Berdasarkan hasil tersebut pengaruh tidak langsung dari pola asuh orang tua permisif memperoleh nilai lebih besar dari pengaruh langsungnya namun memiliki kecenderungan arah yang berubah. Nilai yang diperoleh dari pengaruh tidak langsungnya menunjukan adanya pengaruh negatif antara pola asuh kategori permisif terhadap hasil belajar matematika melalui efikasi diri. sehingga menurunkan hasil belajar matematika anak. Lestari (2012) menyatakan orang tua dengan pola asuh permisif menerima dan memaklumi segala perilaku, tuntutan, dan tindakan anak namun, kurang menuntut sikap tanggung jawab. Orang tua yang demikian akan menyediakan dirinya sebagai sumber daya bagi pemenuhan segala kebutuhan anak sehingga akan memengaruhi sifat manja dan terkadang anak cenderung menjadi pasif. Hal ini akan memengaruhi efikasi diri anak yang secara tidak langsung juga memengaruhi hasil belajarnya.

\section{Simpulan dan Saran}

Hasil Berdasarkan analisis dan pembahasan hasil uji hipotesis yang telah dilakukan, dapat diajukan simpulan dari hasil penelitian sebagai berikut: 1) Pola asuh orang tua kategori otoriter memiliki pengaruh yang signifikan terhadap hasil belajar matematika, . Pola asuh orang tua kategori otoriter berpengaruh terhadap menurunnya hasil belajar matematika pada anak; 2) Pola asuh orang tua kategori demokratis berpengaruh secara signifikan terhadap hasil belajar matematika. Pola asuh orang tua kategori demokratis berpengaruh terhadap meningkatnya hasil belajar matematika pada anak; 3) Pola asuh orang tua kategori permisif berpengaruh secara signifikan terhadap hasil belajar matematika. Pola asuh orang tua kategori permisif berpengaruh terhadap meningkatnya hasil belajar matematika pada anak. 4) Efikasi diri berpengaruh secara signifikan terhadap hasil belajar matematika dengan arah pengaruh positif yang artinya efikasi diri berpengaruh terhadap meningkatnya hasil belajar matematika pada anak; 5) Terdapat pengaruh pola asuh orang tua kategori otoriter terhadap hasil belajar matematika melalui efikasi diri. Pola asuh orang tua kategori otoriter berpengaruh terhadap menurunnya hasil belajar matematika melalui efikasi diri; 6) Terdapat pengaruh pola asuh orang tua kategori demokratis terhadap hasil belajar matematika melalui efikasi diri. Pola asuh orang tua kategori demokratis berpengaruh terhadap meningkatnya hasil belajar matematika melalui efikasi diri; 7) Terdapat pengaruh pola asuh permisif terhadap hasil belajar matematika melalui efikasi diri. Pola asuh permisif berpengaruh secara signifikan terhadap menurunnya hasil belajar melalui efikasi diri. Berdasarkan pembahasan penelitian ini, terdapat saran yang dapat memberikan manfaat kepada.

\section{Daftar Rujukan}

Agung, A. A. Gede. 2014. Metodelogi Penelitian Pendidikan. Malang: Aditya Media Publising

Anwar, A.I. 2009. "Hubungan antara Self Efficacy dengan Kecemasan Berbicara di Depan Umum pada Mahasiswa Fakultas Psikologi Universitas Sumatra Utara". Skripsi (tidak diterbitkan). Medan: Fak. Psikologi USU.

Brooks, Jane.2011. The Process of Parenting Eight Edition. Yogyakarta: Pustaka Pelajar

Pinsensius, Budang., dkk. 2017. Korelasi Pola Asuh Orang Tua dengan Hasil Belajar Matematika pada Siswa Kelas IV SD Negeri 5 Tengadak. Jurnal Pendidikan Dasar PerKhasa, Vol.3, No.2.

Cahyono, Tri. 2015. Statistik Uji Normalisasi. Purwokerto:Yayasan Sanitarian Banyumas (Yasamas).

Dantes, Nyoman. 2012. Metode Penelitian. Yogyakarta: Penerbit Andi Yogyakarta

Departemen Pendidikan Nasional. 2006. Permendiknas Nomor 22 tahun 2006 tentang Standar Isi. Jakarta: Depdiknas. 
Djamarah, Syaiful Bahri. 2017 .Pola Asuh Orang Tua dan Komunikasi dalam Keluarga. Jakarta: Rineka Cipta

Fitriana, Sitti., dkk. 2015. Pengaruh Efikasi Diri, Aktivitas, Kemandirian Belajar dan Kemampuan Berpikir Logis terhadap Hasil Belajar Matematika pada Siswa Kelas VIII SMP. Jurnal of EST. Volume 1, Nomer 2, hal 86-101. ISSN:2460-1497.

Garcia, Fernando and Enrique Gracia. 2009. Is Always Authoritative The Optimum Parenting Style? Evidence from Spanish Families. Adolesence, Vol. 44, No. 173.

Lestari, Sri. 2012. Psikologi Keluarga: Penanaman Nilai dan Penanganan Konflik dalam Keluarga. Jakarta: Prenadamedia Group.

Santrock, John W. 2007. Psikologi Pendidikan Edisi Kedua. Jakarta: Kencana Prenada Media Group.

Septiari, Bety Bea. 2012. Mencetak Balita Cerdas dan Pola Asuh Orang Tua. Yogyakarta: Nuha Medika

Sianipar, Chelsea Sulastry \& Dian Ratna Sawitri. 2015. Pola Asuh Orang Tua dan Efikasi Diri dalam Mengampil Keputusan Karir pada Mahasiswa Tahun Pertama. Jurnal Empati. Vol. 4(4), 1-7

Slameto. 2010. Belajar dan Faktor-Faktor yang Mempengaruhi. Jakarta: Ranika Cipta

Sudaryono. 2017. Metodologi Penelitian. Jakarta Rajawali Pers

Sugiyono. 2017. Metode Penelitian Kuantitatif, Kualitatif, dan R\&D. Bandung: Alfabeta

Surna, I Nyoman \& Olga D. Pandeirot. 2014. Psikologi Pendidikan 1. Jakarta: Penerbit Erlangga

Susanto, Ahmad. 2013. Teori Belajar dan Pembelajaran di Sekolah Dasar Edisi Pertama. Jakarta: Prenadamedia Group.

Syah, Muhibbin. 2017. Psikologi Belajar. Depok: PT. Rajagrafindo Persada.

Taylor, Shelley E., Letitia Anne Peplau \& David O. Sears. 2009. Psikologi Sosial Edisi Kedua Belas. Jakarta: Kencana Prenada Media Group.

Widodo. 2013. Peningkatan Aktivitas Belajar Dan Hasil Belajar Siswa Dengan Metode Problem Based Learning Pada Siswa Kelas Viia Mts Negeri Donomulyo Kulon Progo Tahun Pelajaran 2012/2013

Yusuf, Muri. 2015. Asesmen dan Evaluasi Pendidikan. Jakarta: Prenadamedia Group 